\title{
Neisseria sicca
}

Neisseria sicca, descrita como especie por von Lingelsheim en 1908 y considerada un agente comensal de la orofaringe humana, es un diplococo gramnegativo fastidioso aeróbico, inmóvil y oxidasa positiva. Al igual que todas las especies de este género, requieren de $\mathrm{CO}_{2}$ y cierto grado de humedad para crecer a $35^{\circ} \mathrm{C}$. Se cultiva en agar chocolate, agar sangre de cordero y no se desarrolla en Thayer Martin, dado que este medio inhibe el desarrollo de neiserias comensales excepto $N$. lactámica. La colonia es blanca, opaca, de 1 a $3 \mathrm{~mm}$, adherente; con los días de incubación adquiere una textura rugosa y produce pigmento amarillo verdoso. Entre sus características bioquímicas relevantes se encuentra la producción de ácidos desde sucrosa y fructosa, propiedad que comparte con $N$. subflava y $N$. mucosa y que permite diferenciarlas de neiserias patógenas; por último, la reducción de $\mathrm{NO}_{3}$ es positiva para esta especie.

La sensibilidad in vitro de neiserias comensales se ha mantenido estable a penicilina, ampicilina, cefalosporinas, quinolonas, tetraciclina y macrólidos. Estos microorganismos son considerados resistentes a aminoglucósidos y vancomicina. No hay puntos de corte definidos por el CSLI.

Las infecciones graves por esta especie son inusuales, pero el reporte de casos ha aumentado, especialmente en hospederos inmunocomprometidos. Podemos encontrar en la literatura médica casos de endocarditis, peritonitis en peritoneo-diálisis, meningitis, artritis séptica, bursitis, osteomielitis, neumonía, discitis, abscesos epidurales y bacteriemia. El mayor número de casos reportados de infecciones causadas por neiserias comensales se encuentra en adultos y niños en peritoneo-diálisis crónica; se le ha relacionado principalmente con la ausencia o incorrecto de lavado de manos del paciente en el manejo de la técnica de peritoneo-diálisis. Los casos comunicados plantean que la falla de tratamiento con vancomicina y aminoglucósidos en peritoneo-diálisis debe inducir la sospecha una infección con agentes no típicos. Por último, es importante poner en alerta la relación del aislamiento microbiológico de agentes poco frecuentes, de escasa virulencia, como potenciales patógenos en hospederos con déficit inmunitario.

\section{Referencias}

1. D’Angelo A, Sleiman J, Mongia A, Schoeneman M, Hammerschlag M. Peritonitis caused by Neisseria sicca in a child on chronic peritoneal dialysis. Dialysis \& Transplantation 2007; 36 (8): 457-9.

2. Taegtmeyer M, Saxena R, Corkill J E, Anijeet $\mathrm{H}$ and Parry C M. Ciprofloxacin treatment of bacterial peritonitis associated with chronic ambulatory peritoneal dialysis caused by Neisseria cinerea, J Clin Microbiol 2006; 3040-1.

3. Jung J J, Vu D M, Clark B, Keller F G, Spearman P. Neisseria sicca/ subflava bacteremia presenting as cutaneous nodules in a inmunocompromised host. Pediatric Infect Dis J 2009; 28 ( July): 661-3.

4. Neu A M, Case B, Lederman H M, Fivush B A. Neisseria sicca peritonitis in patient maintaines on chronic peritoneal dialysis. Pediatr Nephrol 1994; 18: 601-2.

5. Novak D J, Bashir K, Baltaro R J, Cavalieri S J. Neisseria sicca/ subflava: continuous ambulatory peritoneal dialysis associated peritonitis. Lab Medicine 2007; 38 : 363-4.

6. Jana W M, Gaydos C H A. Chapter Neisseria. En: Manual of Clinical Microbiology. Patrick R. Murray $9^{\text {th }}$ edition, 2007, pp 601-20.

Dona Benadof $F$. Comité de Microbiología Clínica Laboratorio, Hospital Roberto del Río, Santiago, Chile.

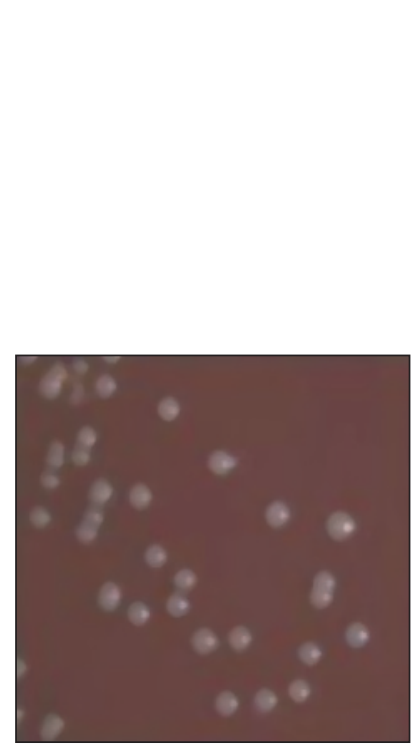

Figura 1. Aspecto de colonia.

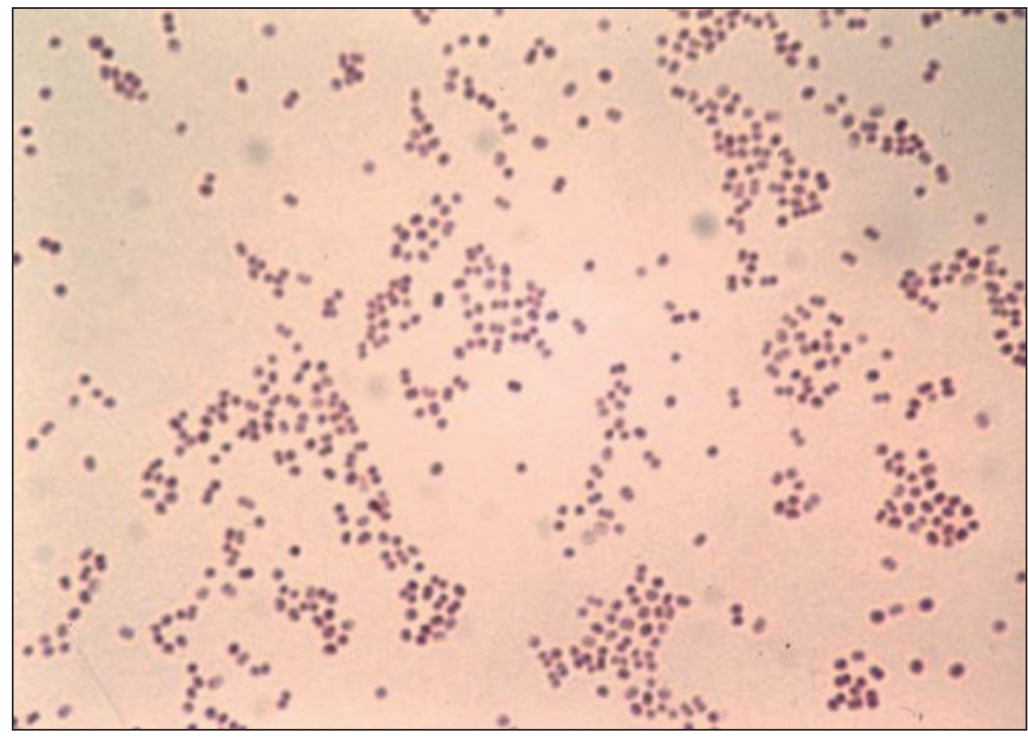

Figura 2. Aspecto al gram.

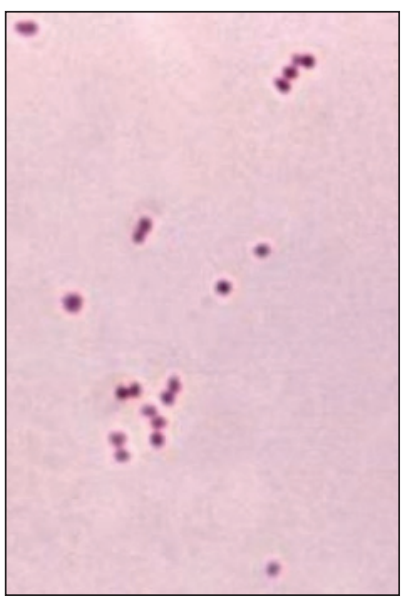

Figura 3. Aspecto al gram. 